\title{
Posmodernisme Kode Visual dalam Iklan Komersial
}

\author{
Ferry Darmawan \\ ABSTRACT \\ The development of ads and advertising raise some sociocultural issues concerning the sign \\ being represented, image being constructed, information being delivered, \\ meaning being acquired, and how everything affects perception, understanding, and public \\ behavior. Advertising is attached to the product, offering images as values and moral reference \\ for public. Advertising creates image of a product and assigns social relationship as reflected \\ on status, prestige, and social class. Postmodernism establish a new form of signification: \\ form follows fun. It is not the meaning, but the interplay between signs that considered \\ the most important thing in advertising.
}

Kata kunci: posmodernisme, iklan, tanda, penandaan.

\section{Konsep Posmodernisme dalam Iklan}

Setiap hari, mulai dari bangun tidur dan memulai aktivitas hingga kembali ke rumah untuk beristirahat malam hari, di mana pun kita berada, ketika kita membaca koran, mendengarkan radio, menonton televisi, jalan-jalan ke mal, belanja ke pasar, niscaya kita akan melihat, mendengar, membaca yang namanya iklan. Seolah-olah iklan hidup dan berada kapan saja dan di mana saja di lingkungan kita.

Di Inggris, iklan cetak pertama dimulai tahun 1472, yaitu berbentuk poster tentang terbitnya buku-buku baru doa gereja yang ditempelkan di pintu gerbang. Surat kabar pertama yang terbit di London tahun 1650 mulai menggunakan iklan terselubung karena pada waktu itu belum dikenal periklanan yang ditata secara profesional seperti sekarang.

Sedangkan di Amerika Serikat (AS), surat kabar pertama yang memasang iklan pada terbitannya adalah Boston Newsletter pada tahun 1704. Pada waktu itu, iklan dirancang dalam surat kabar sebagai headline yang memenuhi halaman depan surat kabar yang terbit secara berkala. Benyamin Franklin dikenal sebagai orang AS pertama yang memperkaya informasi dari iklan dengan menambah suatu tekanan pada segi ilustrasi sehingga efek iklan semakin kuat.

Secara keseluruhan, perkembangan iklan dari masa ke masa telah merefleksikan dunia kehidupan manusia. Terpaan iklan dapat terjadi sepanjang kehidupan seseorang dan berperan untuk peneguhan nilai-nilai baru dan memodifikasi atau membuang nilai-nilai lama. Setiap iklan dirancang untuk memenuhi atau mencapai sasaran tertentu. Iklan sebaiknya dirancang untuk mencapai sasaran spesifik dari pemasar, walaupun tujuan akhir dari program periklanan adalah untuk mendorong terjadi keputusan pembelian oleh konsumen. 
Sasaran periklanan bisa ditentukan berdasarkan klasifikasi mendasar apakah sekadar menginformasikan, membujuk, atau hanya mengingatkan. Periklanan bersifat informatifjika pemasar merancang iklan sedemikian rupa agar halhal penting mengenai produk bisa disampaikan dalam pesan iklan.

Suatu iklan yang baik selalu memperhatikan struktur pesan, gaya pesan, dan appeals pesan yang terkandung di dalamnya. Struktur pesan iklan adalah cara menampilkan pesan dalam bentuk sebuah kesimpulan tersirat dan tersurat dalam kadungan isi pesannya. Gaya pesan adalah cara pemilihan pesan iklan dengan memperhatikan unsur-unsur urutan argumentasi pada pesan iklan, seperti diuraikan lebih dahulu argumentasi yang tidak menyenangkan untuk mengemukakan inti pesan iklan yang menyenangkan. Sedangkan appeals pesan iklan mengacu pada kandungan motif-motif psikologis seperti pesan harus rasional, emosional, atau daya tarik akan ganjaran tertentu. Misalnya iklan menabung di bank M berhadiah mobil mewah.

Sebuah iklan berkaitan dengan sistem tanda di dalamnya. Petanda-petanda merupakan konsep mental yang kita gunakan untuk membagi realitas dan mengategorikannya sehingga kita bisa memahami realitas tersebut. Semiotika memandang komunikasi sebagai pembangkitan makna dalam pesan (baik oleh encoder maupun decoder). Makna bukanlah konsep yang mutlak dan statis yang bisa ditemukan dalam kemasan pesan. Pemaknaan merupakan proses aktif.

Pesan yang disampaikan dalam iklan, merupakan kumpulan tanda-tanda berupa kode. Kode merupakan sistem pengorganisasian tanda. Sistem tersebut dijalankan oleh aturan-aturan yang disepakati oleh semua anggota komunitas yang menggunakan kode tersebut. Ini berarti bahwa studi tentang kode seringkali memberikan penekanan pada dimensi sosial komunikasi.

Menurut Fiske (1990), kode-kode dapat dirumuskan berdasarkan sifat kode, jenis relasi sosial yang dilayaninya, dan sifat khalayaknya. Kode bahasa yang berada pada kelas pekerja dan kelas menengah bisa jadi terdapat perbedaan. Pada komunitas yang sempit, tertutup, dan tradisional ada kecenderungan menggunakan kode-kode terbatas. Kelas pekerja merupakan salah satu contoh untuk komunitas ini. Semua kode bergantung pada kesamaan, yakni suatu kesepakatan di kalangan penggunanya sebagai dasar pemahaman terhadap kode tersebut. Cara yang utama untuk mencapai kesepakatan adalah melalui konvensi dan penggunaan. Konvensi adalah ekspektasi tak tertulis dan tak dinyatakan yang berasal dari pengalaman bersama anggota suatu budaya.

Sebuah iklan, sebagai media informasi dan alat pemasaran sebuah produk, selayaknya memiliki kode-kode yang arbitrer. Dalam teori periklanan, kode dalam iklan merupakan kode yang dirumuskan secara sederhana dan mudah dipahami. Kode arbitrer menekankan makna denotatif.

"Kode dan konvensi membentuk pusat yang sama pada setiap pengalaman kultural. Ini memungkinkan kita memahami eksistensi sosial kita dan untuk menempatkan diri kita sendiri di dalam kebudayaan kita. Hanya melalui kode-kode yang sama kita bisa merasakan dan menyatakan keanggotaan kita ke dalam kebudayaan." (Fiske, 1990)

Dari pandangan ahli-ahli semiotika periklanan, seperti Gillian Dyer, Torben Vestergaard dan Judith Williamson (dalam Piliang, 2004) dapat dilihat bahwa ada dimensi-dimensi khusus pada sebuah iklan yang membedakan iklan secara semiotis dari objek-objek lainnya, yaitu bahwa iklan selalu berisikan unsur-unsur tanda berupa objek yang diiklankan; konteks berupa lingkungan, orang atau makhluk lainnya yang memberikan makna pada objek; serta teks (berupa tulisan) yang memperkuat makna (anchoring).

Sehubungan dengan itu, aspek terpenting penelitian mengenai iklan adalah analisis mengenai konteks yang ditawarkan iklan pada suatu produk yang diiklankan. Melalui konteks tersebut dapat dilihat berbagai persoalan sosial di balik sebuah iklan seperti gender, ideologi, fetisisme, kekerasan simbol, lingkungan, konsumerisme, serta berbagai persoalan sosial lainnya.

Peralihan dari kebudayaan modern menuju kebudayaan posmodern telah mengubah cara 
makna dibangun dan ditafsirkan. Perkembangan posmodernisme menuntut pengkajian tentang artikulasi makna dan ideologi di dalam karya-karya seni harus dirumuskan kembali. Pendekatan konvensional dalam mengkaji bahasa-bahasa estetik harus dirumuskan kembali (Piliang, 2003). Pendekatan posmodernisme terhadap seni lebih menekankan aspek permainan tanda dan kodekode. Karya-karya posmodernisme lebih cenderung memiliki kandungan isi yang bersifat majemuk. Posmodernisme membuka pintu lebar-lebar bagi berinteraksi dan bersimpang siurnya berbagai gaya dari berbagai seniman, periode, kebudayaan, bahkan yang bersifat kontradiktif sekalipun.

Berdasarkan hal di atas, pemahaman terhadap sebuah iklan perlu dirumuskan karena iklan selalu berisikan unsur-unsur tanda berupa objek yang diiklankan, konteks yang memberikan makna pada objek, serta teks yang memperkuat makna. Iklan juga mempunyai tingkatan makna yang kompleks, mulai dari makna eksplisit, yaitu makna yang berdasar apa yang tampak atau makna denotatif, dan makna yang lebih dalam yang berhubungan dengan pemahaman ideologi dan kultural (konotatif).

Iklan merupakan produk kebudayaan suatu masyarakat. Pesan dalam iklan sering dikaitkan dengan sasaran khalayaknya. Iklan merupakan hasil kerja keras, hasil karya cipta orang-orang di belakangnya. Seperti yang dikatakan Paul Belford (dalam Newark, 2002) bahwa "The best ads from that period are still good today, that's the beauty of strong ideas.... These ads relied on alot of copy to communicate their idea." Mempelajari pesan yang terkandung dalam iklan, berarti kita mempelajari berbagai produk hasil olah cipta manusia hingga kebudayaan suatu bangsa.

\section{Iklan sebagai Objek Semiotika}

Secara singkat, semiotika berbicara tentang tanda. Tanda merupakan salah satu unsur yang sering digunakan dalam proses dan aktivitas komunikasi. Salah satu kerangka dalam analisis semiotika diajukan berikut ini:

- Medan wacana (field of discourse): apa yang dijadikan wacana oleh pelaku/ media massa mengenai sesuatu yang sedang terjadi.

- Pelibat wacana (tenor of discourse): menyangkut orang-orang yang dicantumkan dalam teks, sifat orang-orang itu, kedudukannya.

- Sarana wacana (mode of discourse): menyangkut peranan bahasa, penggunaan gaya bahasa (Sobur, 2001).

Iklan, sebagai sebuah objek semiotika, mempunyai fungsi komunikasi langsung. Oleh sebab itu, di dalam iklan, aspek-aspek komunikasi seperti pesan merupakan unsur utama iklan. Iklan adalah sebuah ajang permainan tanda, yang selalu bermain pada tiga elemen tanda yang saling mendukung, yaitu objek, konteks, dan teks.

Berdasarkan semiotika struktural yang dikembangkan Saussure, Roland Barthes mengembangkan dua sistem pertandaan bertingkat, yaitu sistem denotasi dan konotasi. Sistem denotasi adalah sistem pertandaan tingkat pertama, yang terdiri dari rantai penada dan petanda, yakni hubungan materialitas penanda dan konsep abstrak yang ada di baliknya. Pada sistem konotasi, sebagai pertandaan tingkat kedua, rantai penanda/ petanda pada sistem denotasi menjadi penanda, dan seterusnya berkaitan dengan petanda yang lain pada rantai pertandaan lebih tinggi. Secara sederhana dapat diuraikan bahwa pemaknaan tanda pada tingkat denotasi merupakan kode yang bersifat eksplisit, sedangkan pada tingkat konotasi, kode ditampilkan bersifat implisit. Makna

\section{Gambar 1 Model Sistem Pertandaan Barthes} (sumber : Barthes, 1994)

\begin{tabular}{|c|c|c|}
\hline 3 Connotation & Sr : Rhetoric & Sd : ideology \\
\hline 2 Denotation & $\mathrm{Sd}$ & \\
\hline 1 Real System & $\mathrm{Sr}$ & \\
\hline
\end{tabular}


tersembunyi ini, menurut Barthes, merupakan kawasan ideologi atau mitologi, seperti tampak pada model sistem pertandaan dari Barthes (1994) dalam gambar 1 .

\section{Posmodernisme Kode Visual Iklan}

Perkembangan iklan dan periklanan dewasa ini telah memunculkan berbagai persoalan sosial kultural mengenai iklan, khususnya mengenai tanda yang digunakan, citra yang ditampilkan, informasi yang disampaikan, makna yang diperoleh, serta bagaimana semuanya mempengaruhi persepsi, pemahaman, dan tingkah laku masyarakat. Di dalam iklan, menurut Piliang (2003), tanda-tanda digunakan secara aktif dan dinamis, sehingga orang tidak lagi membeli produk untuk pemenuhan kebutuhan, melainkan membeli makna-makna simbolik, yang menempatkan konsumen di dalam struktur komunikasi yang dikonstruksi secara sosial oleh sistem produksi/ konsumsi. Konsumen dikondisikan lebih terpesona dengan makna-makna simbolik ini ketimbang dengan fungsi yang sebenarnya pada sebuah produk. Sebuah iklan biasanya menawarkan sebuah citra (image) yang dalam konteks bahasa iklan dapat dijelaskan sebagai gambaran mental dari sesuatu yang sebenarnya tidak ada. Dalam fenomena iklan dan citra yang ditawarkan di dalamnya, selalu saja ada celah yang membatasi antara penampilan sesuatu dengan makna yang sesungguhnya.

Kejayaan modernisme dianggap sudah berakhir oleh banyak kalangan, naik sebagai penggayaan maupun konsep ideologinya. Kenyataan ini memicu munculnya alternatif pemikiran baru sebagai upaya mencari bentuk baru. Munculnya gagasan mengenai posmodernisme merupakan upaya memberikan pemikiran baru tadi.

Terdapat kesepakatan umum bahwa posmodernisme merupakan fenomena perubahan sosial budaya yang terjadi pada dekade tahun 1970an, yang merupakan cerminan situasi masyarakat Barat pada dasawarsa tersebut yang memacu polarisasi kapitalisme dan konsumerisme secara luar biasa di lingkungan masyarakat Eropa -
Amerika. Upaya meninggikan peran makna objek, posmodernisme mendukung makna perlambangan atau kiasan. Dengan demikian, objek tidak lagi semata-mata alat bantu, tetapi lebih jauh lagi sebagai alat komunikasi visual. Karena bertentangan dengan rasionalitas modern, posmodernisme memberikan tekanan yang sangat besar bukan pada rasionalitas tapi pada kepekaan, bukan pada fungsi tapi pada khayal, bukan pada konsep tapi bentuk visual, bukan pada objek tapi keintiman. Jencks, dalam bukunya The Language of Post-Modernism Architecture, mengistilahkannya sebagai konsep dual-coding, yaitu makna ganda. Artinya, bentuk desain tidak seharusnya hanya dipahami oleh si perancang dan kalangannya, namun juga harus bisa dimengerti oleh masyarakat umum sebagai pemakai atau pengamat (Sachari dan Sunarya, 2002).

Wacana posmodernisme pernah hadir di kancah perdebatan intelektual Indonesia, dimulai dari peristiwa Kongres Kebudayaan Nasional 1991, Majalah Prisma 1993, juga di surat kabar. Gejala posmodernisme dapat dilacak sejak akhir tahun 1980-an hingga kini. Gejala ini terlihat pada desain produk industri, pusat pertokoan dan perkantoran, kota satelit, kondominium, gaya busana, hingga desain komunikasi visual seperti desain perwajahan buku dan tampilan grafis pada kaos oblong.

Posmodernisme tidak saja menolak mengacunya penanda pada makna ideologis yang konvensional, akan tetapi juga menolak menjadikan fungsi sebagai referensi dominan dalam pertandaan, sebagaimana yang terdapat pada modernisme. Posmodernisme mengambil tandatanda dari periode klasik dan modern untuk menciptakan satu rantai pertandaan yang baru dengan menanggalkan makna-makna konvensional untuk menghanyutkan diri dalam permainan bebas penanda-penanda sebagaimana yang dikemukakan Derrida dan Baudrillard. Di dalam diskursus seni posmodernisme, bukan makna-makna ideologis yang ingin dicari, melainkan kegairahan dalam bermain penanda (Piliang, 2003).

Menurut Ferdinand de Saussure (dalam Piliang, 2003), sebuah tanda terdiri dari sebuah penanda (signifier) dan petanda (signified). 
Penanda mengacu pada petanda, yang selanjutnya mengacu pada referensi atau realitas. Dalam pandangan Saussurean, 'makna' adalah apa-apa yang ditandakan (petanda), yakni kandungan isi. Hubungan antara penanda dengan petanda bersifat arbiter, sebab tidak ada keterkaitan logis, misalnya antara kata 'pohon' dan sebatang 'pohon' berarti pohon di dalam satu komunitas, maka ia akan menjadi satu konvensi, dengan pengertian ia berada tetap pada posisi yang disepakati komunitas tersebut.

Dalam upaya menyingkap kode-kode dan tanda-tanda seni posmodernisme, tampaknya perlu dilakukan peninjauan kembali terhadap semiotika struktural sebagai satu pendekatan dalam analisis tanda, disebabkan permasalahan epistemologi yang muncul. Peninjauan kembali dan pembaharuan terhadap semiotika struktural telah ditawarkan oleh para pemikir pos-strukturalis, seperti Derrida, Foucault, Barthes, Kristeva, Deleuze \& Guattari, dan Baudrillard. Dalam berhadapan dengan teks-teks yang tak konvensional, seperti posmodernisme, para pemikir ini mengembangkan model pendekatan linguistik yang cenderung menekankan aspek wacana dari sebuah teks. Ia lebih menyoroti aspek produksi dan penggunaan tanda-tanda secara nyata pada satu komunitas bahasa tertentu ketimbang konvensi yang menopangnya. Menurut Harland (1987), tanda-tanda yang dikembangkan di dalam diskursus posmodernisme sebagai tanda-tanda 'anti sosial', yaitu tanda-tanda yang memiliki tiga kualitas utama, yaitu ia berubah, berkembang biak, dan bersifat materi.

Dalam kaitannya dengan relasi pertandaan posmodernisme, Baudrillard membuat sebuah perbandingan semiosis yang menarik antara karya Bauhaus (wakil modernisme) dengan karya posmodernisme. Menurut Baudrillard, Bauhaus dalam setiap ungkapan karya memberikan satu formula yang diasumsikan bersifat universal, bahwa pada setiap obyek ada satu petanda atau makna yang bersifat determinan dan objektif, yaitu fungsi. Berbeda pada karya posmodernisme, apa yang disebut tanda itu bersifat sangat mendua, dan mempunyai hubungan yang tidak harmonis dengan fungsi. Baudrillard cenderung mengatakan 'penanda sudah mati' di tangan posmodernisme, disebabkan keterpesonaannya pada permainan penanda (misalnya ornamentasi), yang oleh modernisme dianggap sebagai parasit dari fungsi -berlebihan, sampah, aneh, ornamentasi, mubazir, kitsch (Piliang, 2003).

Posmodernisme mengembangkan satu prinsip baru pertandaan, yaitu form follows fun, di dalam wacana posmodernisme. Bukan makna-makna ideologis yang ingin dicari, melainkan kegairahan dalam bermain dengan penanda. Berdasarkan semiotika struktural yang dikembangkan Saussure, Roland Barthes mengembangkan dua sistem pertandaan bertingkat (staggered systems), yang memungkinkan untuk dihasilkannya makna yang juga bertingkat-tingkat, yang disebut sistem denotasi dan konotasi. Sistem denotasi adalah sistem pertandaan tingkat pertama, yang terdiri dari rantai penanda dan petanda, yakni hubungan materialitas penanda dan konsep abstrak yang ada di baliknya atau antara tanda dan rujukannya pada realitas yang menghasilkan makna yang eksplisit, langsung, dan pasti. Pada sistem konotasi - atau sistem pertandaan tingkat kedua - rantai penanda/ petanda pada sistem denotasi menjadi penanda, dan seterusnya berkaitan dengan petanda yang lain pada rantai pertandaan lebih tinggi.

Menurut Barthes, pada tingkat denotasi, bahasa menghadirkan konvensi atau kode-kode sosial yang bersifat eksplisit, yakni kode-kode yang makna tandanya segera tampak ke permukaan berdasarkan relasi penanda dan petandanya. Denotasi adalah tanda yang penandanya mempunyai tingkat konvensi atau kesepakatan yang tinggi. Sebaliknya pada tingkat konotasi, bahasa menghadirkan kode-kode yang makna tandanya bersifat implisit, yaitu sistem kode yang tandanya bermuatan makna-makna tersembunyi. Makna yang tersembunyi ini merupakan kawasan dari ideologi atau mitologi. Konotasi menciptakan makna-makna lapis kedua, yang terbentuk ketika penanda dikaitkan dengan berbagai aspek psikologis, seperti perasaan, emosi, atau keyakinan.

Selain itu, Barthes juga melihat makna yang 
Tatanan Pertama

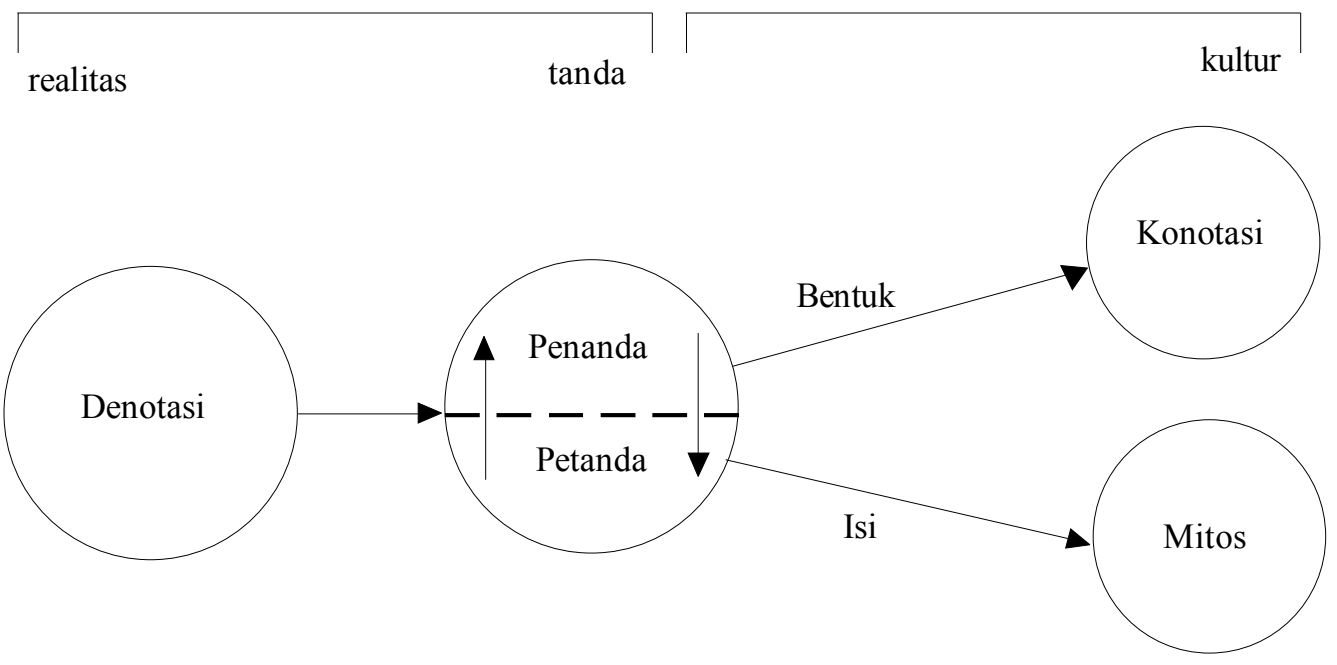

Gambar 2. Tingkatan Tanda Semiotika Barthes

(Sumber : Fiske, 2004)

lebih dalam tingkatannya, akan tetapi lebih bersifat konvensional, yaitu makna-makna yang berkaitan dengan mitos. Tingkatan tanda dan makna Barthes ini, dapat digambarkan seperti tampak pada gambar 2.

Menurut Barthes, mitos adalah cerita yang digunakan suatu kebudayaan untuk menjelaskan atau memahami beberapa aspek dari realitas atau alam. Mitos merupakan cara berpikir dari suatu kebudayaan tentang sesuatu., cara untuk mengkonseptualisasikan atau memahami sesuatu. Bila konotasi merupakan pemaknaan tatanan kedua dari penanda, mitos merupakan pemaknaan tatanan kedua dari petanda. Barthes menegaskan bahwa cara kerja pokok mitos adalah untuk menaturalisasikan sejarah.

\section{Makna Denotasi dan Konotasi dalam Iklan Komersil: Contoh Kasus}

Dalam masyarakat konsumen, memproduksi sebuah benda bukan proses yang berdiri sendiri, melainkan harus diiringi dengan memproduksi tontonan yang mengiringi benda tersebut. Produk tontonan inilah yang diisi berbagai tanda, citra, dan makna yang dikemas dalam bentuk iklan. Iklan yang mengiringi sebuah produk, menawarkan citracitra sebagai acuan nilai dan moral masyarakat. Iklan menciptakan citra sebuah produk dan hubungan sosial di dalamnya, seperti status, prestise, kelas sosial.

Iklan memberikan ilusi-ilusi tentang sensualitas, kehidupan selebritis, gaya hidup/ lifestyles di balik sebuah komoditas. Konsumer dengan demikian,menjadi konsumer ilusi, yang bukan membeli produk tapi membeli ilusi, yang membeli relasi sosial bukan fungsi dari produk. Ilusi-ilusi yang ditawarkan oleh iklan, tanpa disadari, melulu tentang kebaruan. Makna baru yang ditawarkan selalu tampak pada pesan-pesan dalam iklan, ketika ketuaan tidak lagi ditentukan dengan nilai guna, tapi semata tahun pembuatan sebuah produk. Kata baru yang lugas, misalnya, iklan susu “Ini dulu, baru itu..." yang menjadi ikon dari pembentukan imaji yang populer, atau salah satu produk shampoo yang mengiklankan "seperti baru keramas". Namun ada juga iklan yang tidak menggunakan kata baru secara eksplisit, seperti iklan deterjen yang selalu mengomparasi antara baju lama seperti "baru" dengan baju baru. Selain 
itu, iklan lain yang memunculkan nilai kebaruan dengan format lain, yaitu barang baru. Iklan handphone, misalnya, yang selalu memunculkan produk-produk baru dalam hitungan bulan bahkan hari.

Semua iklan "baru" tadi hanya ada satu tujuan yaitu untuk dikonsumsi. Jika konsumsi kita pahami sebagai suatu proses untuk menghabiskan atau mentransformasikan nilai-nilai yang disimpan sebuah benda, maka jelaslah kini, setiap produk yang diiklankan pasti telah diberi nilai baru. Nilai atau kegunaan baru itulah yang menjadi daya tarik suatu produk. mengungkapkan pesan yang mengiringi sebuah produk. Iklan-iklan ini akan dikaji secara makna denotasi dan konotasi yang diberikan oleh Roland Barthes. Iklan dipilih secara acak yang muncul pada satu terbitan surat kabar nasional.

\subsection{Iklan VW Caravelle}

Makna denotasi dalam iklan ini adalah menampilkan desain interior sebuah ruangan yang cukup luas. Ini dapat terlihat dari ukuran bangku yang berjajar tiga buah serta jarak antara bangku yang berhadap-hadapan cukup jauh dengan meja di tengah-tengah. Desain interior yang ditampilkan

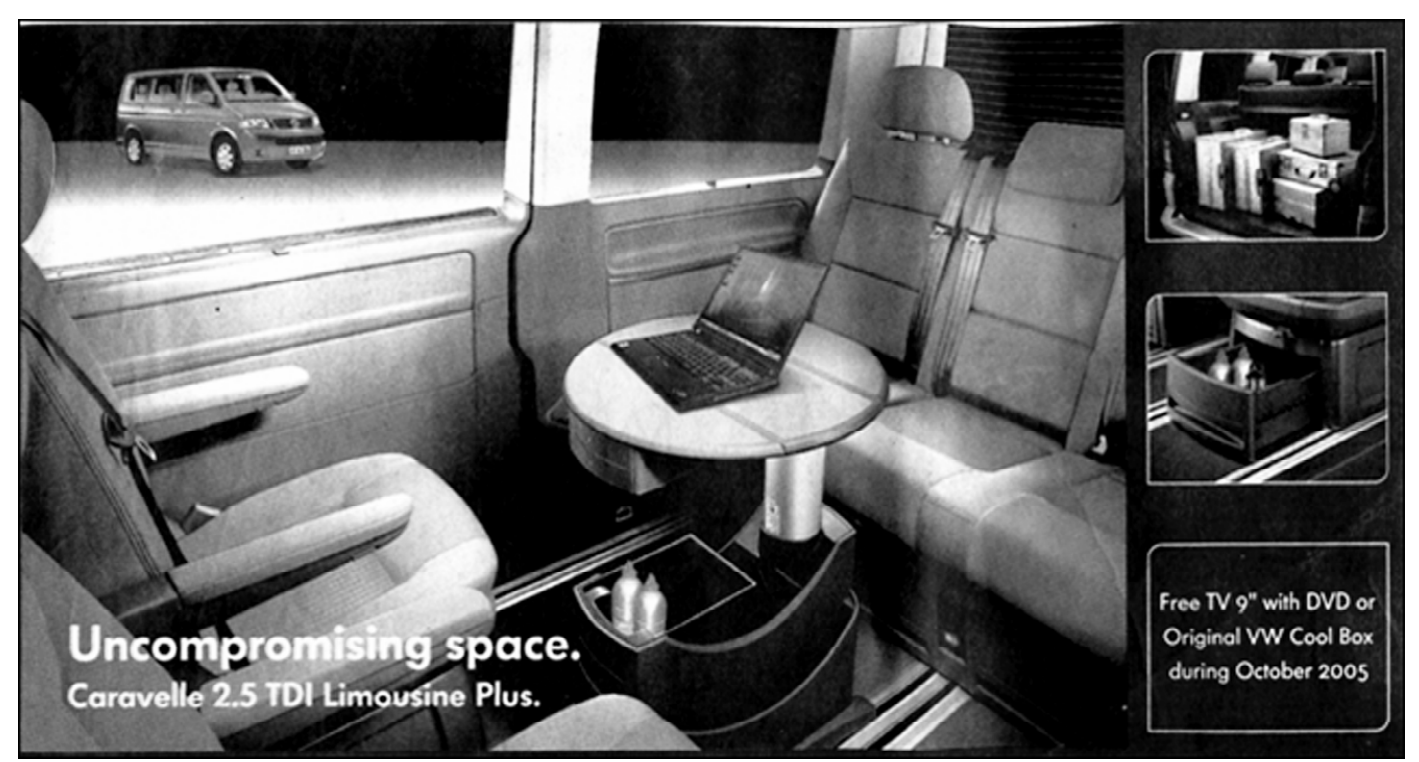

Gambar 3. Iklan VW Caravelle

Manusia modern yang berada dalam bayangbayang kapitalisme ini selalu diserang dengan nilainilai kebaruan tadi. Kapitalisme mampu mengubah penciptaan sebuah produk yang memiliki beragam varian menjadi sebuah kebutuhan akan status, prestise, hingga gaya hidup. Manusia modern merasa menjadi orang baru jika sudah mencuci dengan deterjen varian terbaru, memakai baju baru, atau menggenggam handphone tipe terbaru.

Beberapa iklan berikut ini memberikan gambaran kepada kita bagaimana sebuah iklan bermain tanda, citra dan makna dalam adalah interior sebuah mobil yang diwakilkan oleh sabuk pengaman yang ada pada setiap kursi. Makna luas yang ditampilkan dalam iklan ini juga didukung dengan teks yang berada di sudut bawah, "Uncompromising Space" (anchoring). Di atas meja juga terdapat sebuah notebook dalam keadaan sedang menyala. Di latar belakang, di luar jendela ruangan, tampak sebuah mobil VW berwarna biru. Pada foto insert tampak gambar bagasi yang cukup luas dengan barang-barang yang menumpuk, serta gambar kotak pendingin. Inilah makna denotasi pada iklan di atas. Jika dikaji 
secara lebih dalam pada tingkatan konotasi, iklan ini menampilkan betapa luasnya interior mobil yang digambarkan bagai sebuah ruang kerja yang dibalut dengan kemewahan. Ruang interior mobil bukan hanya sekadar menyediakan tempat bagi penumpang, tapi bisa juga digunakan sebagai ruang kerja yang dilengkapi dengan televisi dan lemari pendingin. Bagaimana kabin mobil VW ini divisualisasikan sedemikian rupa seperti bukan menawarkan space yang luas diibaratkan seperti ruang kerja di rumah.

\subsection{Iklan Handphone Samsung SGH D600}

Pada iklan ponsel Samsung ini, ditampilkan tanda-tanda visual yang menampilkan seorang pria muda, dengan penampilan trendy. Pada telinganya terpasang sebuah alat handsfree sebagai asesoris

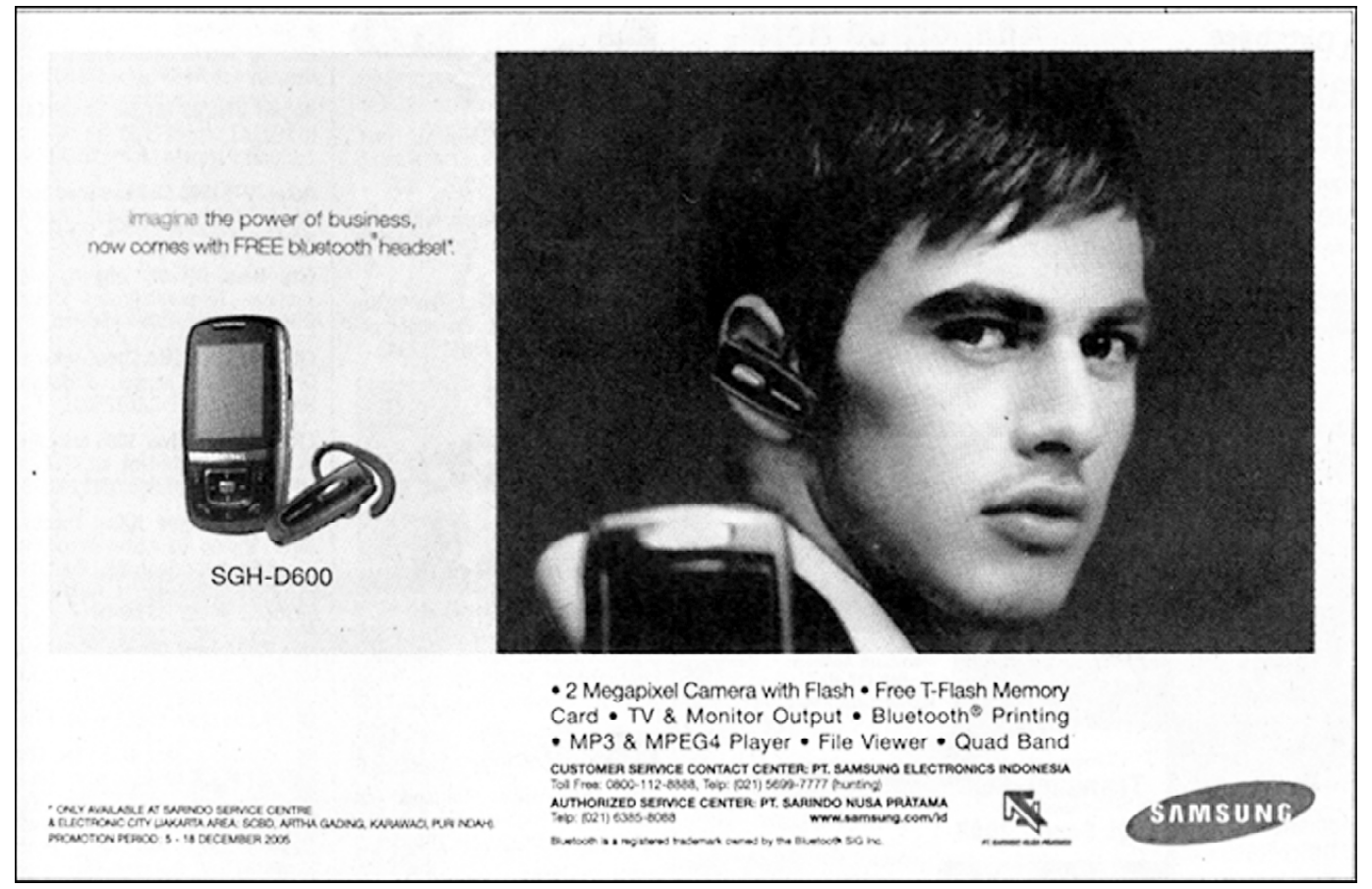

Gambar 4. Iklan Samsung SGH-D600

merupakan kabin mobil. Hal ini ditekankan dengan teks yang mengiringinya, "Uncompromising Space...Limousine plus". Iklan ini bukan hanya menawarkan sebuah produk kendaraan, tetapi menawarkan sebuah kenyamanan dan kemewahan. Makna prestise ketika menggunakan mobil ini akan tampak pada pemiliknya. Pemunculan notebook, juga mewakili para kaum eksekutif yang selalu bekerja di mana pun berada. Pemunculan gambar mobil di latar belakang, menekankan pesan betapapun sebuah mobil hanyalah sebesar mobil pada umumnya, namun mobil ini berbeda, ia handphone. Lelaki ini sedang menggenggam ponsel tersebut di tangannya. Pada bagian kiri, terdapat teks yang menjadi anchor dari produk ini, yaitu kalangan pebisnis. Tampilan produk ponsel juga didesain elegan dengan balutan warna hitam. Demikianlah tataran denotasi pada iklan ini. Sedangkan pada tataran konotasi, iklan ini menampilkan manusia modern yang serba praktis, tidak mau rumit, dan selalu mobile. Gaya, yang terkesan gaul, namun tetap elegan, dan merupakan manusia pekerja yang selalu membutuhkan komunikasi ke mana pun dan di mana pun dia 
berada. Produk yang berbasiskan nirkabel menunjukkan kepraktisan manusia modern. Headset tidak lagi menggunakan kabel, tapi sudah menggunakan teknologi gelombang udara yang menghilangkan fungsi kabel sebagai penghantar data. Kalimat "imagine the power of bussiness" memberikan tekanan bahwa ponsel ini ditujukan pada pasar tertentu yang menciptakan status sosial tertentu bagi pemiliknya. Dominasi penggunaan warna hitam pada visual iklan ini juga menguatkan pesan bahwa pengguna ponsel ini merupakan kalangan eksekutif muda yang selalu memperhatikan gaya formal. Hitam diidentikan dengan sifat elegan dalam kepribadian seseorang. Ia juga diibaratkan dengan kejantanan, macho, lelaki sejati. Menggunakan ponsel ini dengan handsfreenya memberikan status kejantanan bagi pria muda seperti halnya dalam film-film action James Bond atau Mission Imposible. Maskulinitas tampak kental dalam iklan ini, di mana penggambaran pria metropolis dengan gaya rambut dan kumis tipis memperkuat konotasi masyarakat terhadap gaya pria modern.

\subsection{Iklan Handphone Nokia 6600}

Pada iklan Nokia ini, ditampilkan beberapa anak muda, laki-laki dan perempuan, yang sedang berada di sebuah kafe, karena terdapat banyak gelas di atas meja masing-masing dari mereka. Mereka semua sedang menggenggam ponsel. Tampak di antara mereka sedang bercakap-cakap dengan pandangan yang saling menggoda. Ini

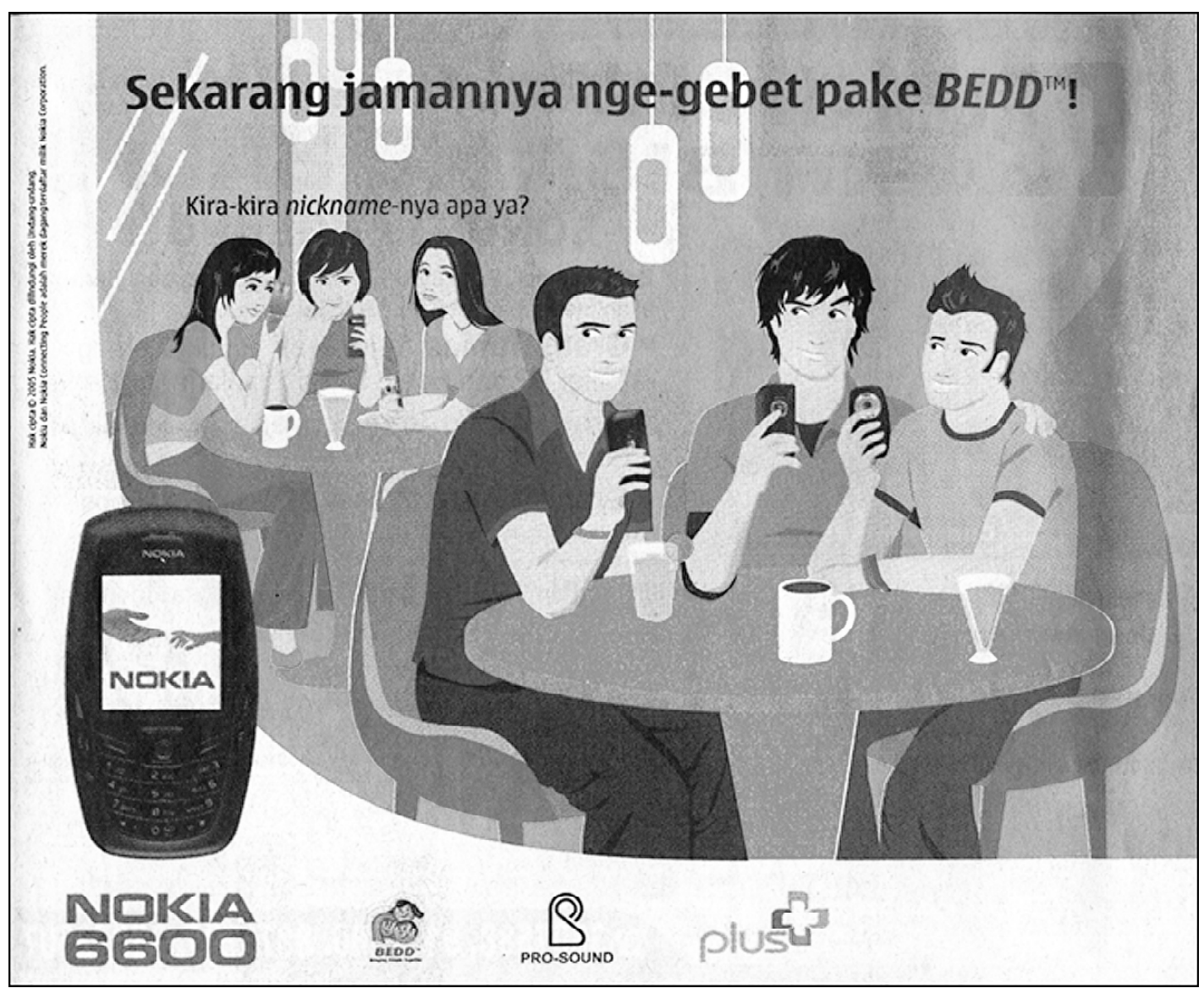

Gambar 3. Iklan Nokia 6600 
ditambah dengan teks "kira-kira nickname-nya apa ya?" yang memberikan anchor pada kita bahwa mereka sedang membicarakan lawan jenisnya satu sama lain. Itulah makna denotasi pada iklan ponsel nokia 6600. Sedangkan pada tingkat konotasi, tampak jelas makna kebaruan digunakan dalam iklan tersebut. Produk ponsel ini yang sebenarnya merupakan produk lawas yang dirilis kembali dengan mengubah warna casing dan menambahkan muatan sosial berupa pasar yang dituju. Remaja gaul yang tidak ingin dianggap ketinggalan jaman, kurang pergaulan, atau ketinggalan perkembangan teknologi. Keceriaan yang ditampilkan dalam iklan ini memberikan wacana tersendiri bagi sebuah komunitas remaja. Warna-warni dalam gambar menandakan perasaan senang, bahagia, keceriaan dalam kehidupan remaja. Kebiasaan komunitas remaja era posmodern yang gemar hura-hura, bersenang-senang, fun, serta gemar berkumpul di kafe. Unsur kebaruan lainnya adalah kalimat "sekarang jamannya..." yang merupakan penegasan kembali terhadap sebuah inovasi yang menggeser nilai-nilai makna dari sebuah perkenalan, silaturahmi secara konvensional. Transformasi proses komunikasi ditampilkan di mana komunikasi konvensional dengan lisan dapat ditinggalkan dan diubah dengan komunikasi tulisan hanya menggunakan produk ponsel yang ditawarkan. Desain sebuah ponsel menjadi penengah jalinan hubungan antarmanusia.

\subsection{Iklan Pembalut Carefree}

Iklan Carefree ini menampilkan elemen-elemen penandanya seorang wanita yang sedang diukur badannya oleh seorang lelaki, di mana wajah si wanita tampak terpotong dan wajah si lelaki sejajar dengan bagian pinggul si wanita. Wanita tersebut mengenakan pakaian dari bahan tidak terlalu tebal. Si lelaki tampak sedang sibuk memperhatikan alat ukur badan yang biasa digunakan di rumah jahit. Profesi si lelaki sebagai desainer pakaian didukung dengan latar belakang yang menampilkan patungpatung yang biasa digunakan untuk meletakkan pakaian yang selesai dijahit. Inilah yang ditampilkan iklan ini dalam tingkat denotasi. Pada

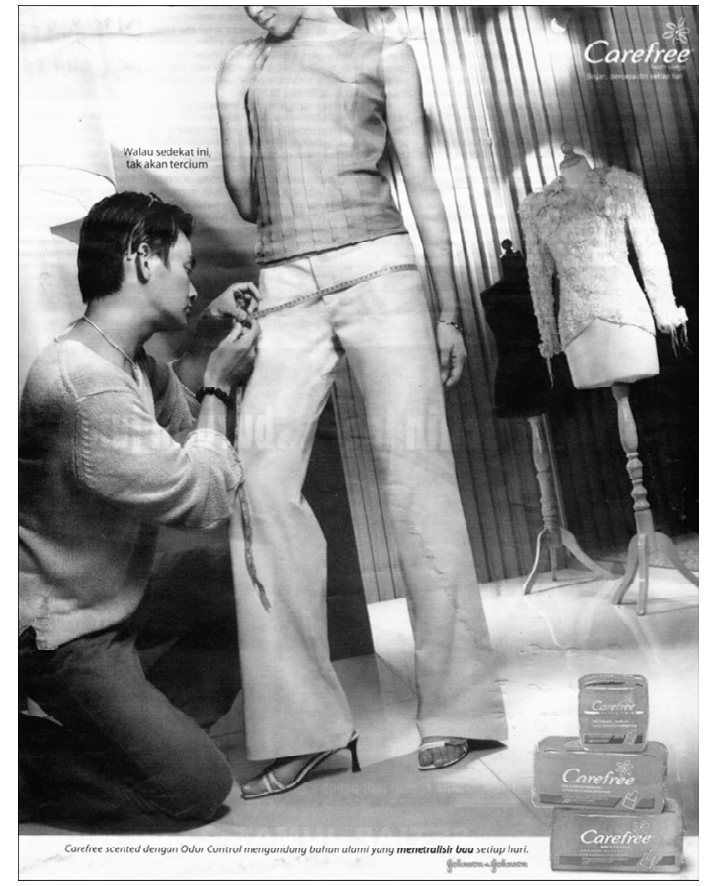

Gambar 6. Iklan Pembalut Carefree

tingkatan konotasi, lelaki yang digambarkan dengan pakaiannya yang berbahan tipis, dan kacamata yang diletakkan di atas kepala, seperti menggunakan bando (penahan rambut pada wanita), memberikan konotasi sifat feminisme pada kaum lelaki. Pekerjaan desain pakaian, jahit menjahit, bukan hanya pekerjaan wanita seperti mitos yang berlaku di masyarakat. Penggunaan gelang dan kalung pada si pria juga menambah makna konotasi sisi feminisme pada diri lelaki. Dalam iklan ini juga berkonotasi bahwa bagaimana peran wanita dalam masyarakat telah mengalami perubahan. Wanita tidak lagi didominasi oleh kaum pria, wanita era posmodern menjadi wanita yang tangguh, bisa mengatasi masalahnya sendiri, dan bahkan bisa mendominasi peran di atas pria. Makna konotasi lain dalam iklan ini juga bisa diuraikan mengenai perkembangan desain hingga masa posmodernisme. Penempatan patung hitam sebagai perwakilan era pramodern, patung dengan pakaian bergaya modernisme dan posisi manusia posmodern di bagian depan dengan gaya 
posmodern seolah menjelaskan pada kita bagaimana desain mengalami perubahan. Dari yang bergaya klasik hingga modern.

\subsection{Iklan Kartu Kredit BNI}

Makna denotasi dalam iklan kartu kredit BNI ini adalah seorang pria yang sedang bersantai di tangga eskalator setelah habis berbelanja banyak. Tampak deretan kantong belanjaan yang diletakkan berjajar di tangga eskalator tersebut. Sedangkan makna konotasi dalam iklan ini adalah tampak bagaimana budaya konsumtifisme dalam mayarakat posmodern. Kartu kredit yang merupakan ciri khas kebudayaan masyarakat konsumer di era konsumerisme memberikan kemudahan bagi masyarakat untuk memenuhi

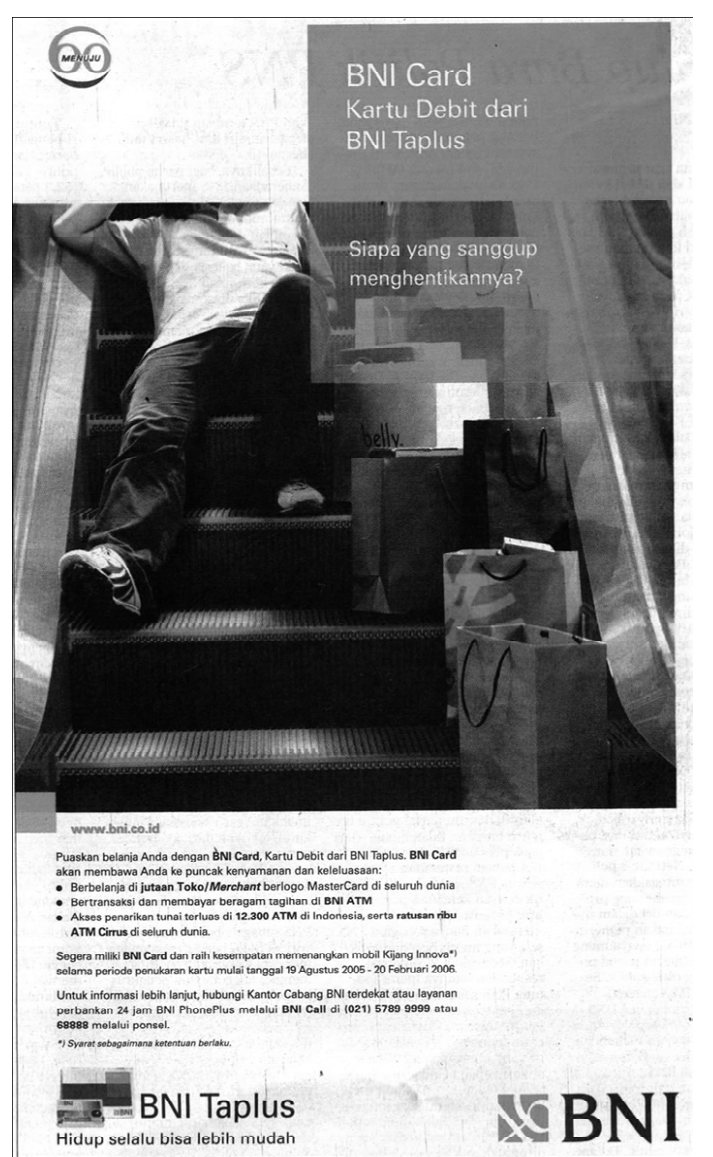

Gambar 7. Iklan Kartu Kredit BNI kebutuhannya. Budaya konsumtif masyarakat modern ditunjang dengan kemudahan berbelanja hanya dengan menggunakan sebuah kartu seukuran kartu nama, menambah panjang daftar dampak kapitalisme global yang digawangi oleh bangsa barat. Euforia dalam konsumtifisme makin tak bisa dibendung lagi. Bahkan iklan ini juga telah memberikan pada kita sebuah gambaran bagaimana naluri manusia gemar akan berbelanja seperti yang tercantum dalam teks, "Siapa yang sanggup menghentikannya?" Bahkan budaya belanja ini bukan lagi milik kaum wanita saja seperti yang dimitoskan, melainkan pria modern juga memiliki sifat feminisme ini, yaitu hobi berbelanja.

\section{Daftar Pustaka}

Barthes, Roland. 1994. Elements of Semiology, New York: Hill and Wang.

Fiske, John. 2004. Cultural and Communication Studies. Jogyakarta: Jalasutra.

Hutcheon, Linda. 2004. Politik Postmodernisme. Yogyakarta: Jendela.

Liliweri, Alo. 1992. Dasar-dasar Komunikasi Periklanan. Bandung: Citra Aditya Bakti.

Newark, Quentin, 2002, What is Graphic Design?, Route Suisse, RotoVision Book.

Piliang, Yasraf Amir. 1999. Hiper-Realitas Kebudayaan. Yogyakarta: LKiS.

2004. Posrealitas: Realitas Kebudayaan dalam Era Posmetafisika. Yogyakarta: Jalasutra.

Sachari, Agus, \& Yan Yan Sunarya. 2002. Sejarah dan Perkembangan Desain \& dunia kesenirupaan di Indonesia. Bandung: Penerbit ITB.

Sachari, Agus. 2005. Pengantar Metodologi Penelitian Budaya Rupa. Jakarta: Erlangga.

Sobur, Alex. 2001. Analisis teks media : Suatu Pengantar untuk Analisis Wacana, Analisis Semiotik, dan Analisis Framing. Bandung: Remaja Rosda Karya. 
Sutisna. 2001. Perilaku Konsumen dan Komunikasi Pemasaran. Bandung: Remaja Rosdakarya.
Jurnal Komunikasi Mediator, Volume 5 Nomor 2 2004, Fikom Unisba. 